\title{
Impact of Application of Data Mining in the Lebanese Banking Sector
}

\author{
Kamel Hassan Kalakech ${ }^{1} \&$ HasanYousef El-Mousawi ${ }^{1}$ \\ ${ }^{1}$ Associate Professor, Lebanese University, Beirut, Lebanon \\ Correspondence: HasanYousef El-Mousawi, Faculty of Economical Sciences and Business Administration, \\ Lebanese University, Beirut, Lebanon. Tel: 961-328-1831 or 961-7008-8037. E-mail: h_mousawi@hotmail.com
}

Received: June 28, 2019

Accepted: July 17, 2019

Online Published: July 25, 2019

doi: 10.5539/ijef.v11n8p101

URL: https://doi.org/10.5539/ijef.v11n8p101

\begin{abstract}
This study aims at showing the level of implementing concepts and tools of data mining in the banking sector in Lebanon in addition to its constituent domains. The researchers adopt the descriptive-analytical method which is based on a questionnaire distributed on the society of the study. The researchers found that there is an interest in applying concepts of data mining in managing operations in the Lebanese banking sector. The researchers concluded that there is difference among the respondents' opinions regarding applying concepts of data mining in managing operations in Lebanese banks as related to difference in experience, in job levels and in qualifications.
\end{abstract}

Keywords: data mining, banking, classification, clustering, data warehouse

\section{Introduction}

There is an overwhelming amount of data: scientific, medical, demographic, financial and marketing data. People have no time to examine this data. Human attention has become the precious resource. So, we had to find ways to automatically analyze the data, classify it, discover and characterize trends in it, and spot anomaly.

The conventional way of extracting information is time-consuming and costly at the same time. With all the new computer technology available, it can process data beyond human capacity and speed, and much more efficiently than ever before. A large number of researchers are becoming more and more interested in data mining after its techniques developed and succeeded in such domains as finance, investing, marketing, accounting and banking.

In fact analyzing large mounds of data is a must. Every enterprise benefits from collecting and analyzing its data: banks can detect trends and anomalies in their customer accounts records, search engines can do better ranking and placement of ads, and environmental and public health agencies can spot patterns and abnormalities in their data. The list continues, with cyber security and detection of computer network intrusion; monitoring the energy consumption of household appliances; business and financial intelligence data; sporting trends in blogs, and many more. Storage is inexpensive and getting even less, so are data sensors. Thus, collecting and storing data is much easier than before. So, the problem becomes how data should be analyzed.

After going through previous studies about data mining, it becomes evident that there is not enough attention given to the philosophical foundations of data mining. As a result, there are many basic controversial questions which remain incomprehensible regarding the definition, foundation and scope of data mining. Introducing technology, mainly data mining, into the business world is a great innovation which helped organizations develop their perspective into business.

Computerizing our society has considerably improved our abilities to generate and collect data from various sources. A huge amount of data has flooded into almost every aspect of our lives. This unstable growth in stored or transitory data has created an urgent need for new techniques and automated tools that can intelligently assist us in transforming these vast mounds of data into useful information. This has led to the generation of a promising, flourishing frontier in computer science called data mining and its various applications.

\section{Literature Review}

Data mining emerged during the late 1980s, made great strides during the 1990s, and continues to prosper into the new millennium. This review of literature focuses on how data mining techniques are used for different application areas, especially in the banking sector to automatically, analyze the data, classify it, discover and characterize trends in it, and spot anomalies. 
Tae et al. (1999) aimed at how data mining approach develops a bankruptcy prediction model suitable for normal \& economic crisis conditions. It examines the dynamics of model change from ordinary to crisis condition and provides an interpretation of bankruptcy classification. The bankruptcy projection model showed that the major variables in predicting bankruptcy were "cash flow to total assets" and "production of capital" under usual circumstances and "cash flow to liabilities", "Fixed assets to long term liabilities and stockholders' equity" under emergency conditions. The accuracy rate of final prediction models in normal conditions and in emergency conditions was found to be 83.3 percent and 81.0 percent respectively. When the normal model was applied in emergency situations, projection accuracy dropped considerably in the case of bankruptcy classification (from 66.7 percent to 36.7 percent).

Özekes and Çamurcu (2002) prepared a function in data mining regarding classification and prediction. In this function, by examining the credits granted to customers in the past by a bank and the credits contracts that are ended, the decision tree and classification rules were formed. Following this, by using these classification rules, the status of repayment of customers' credits with credit contracts continuing was estimated.

Aşan (2007), aimed at classifying the socio-economic characteristics of clients, utilizing credit cards. With priority as a functional conclusion, the individual banking and credit cards are defined; the place and importance of this concept in this country are explained and bank customers who are using credit cards are put into groups employing clustering analysis. Bank clients which are placed into relation with this method, are classified into three groups, according to their socio-economic characteristics and into three sets. According to the three sets, it is observed that the customers differ, according to ten socio-economic indicators.

Linoff and Berry (2011) have given the Data mining techniques for marketing, Sales and customer relationship management (CRM), also Han and et al. (2011) have given the same approach.

Devale and Kulkarni (2012) investigate the use of various data mining techniques for knowledge discovery in the life insurance business. They introduced different ways for discovering knowledge in the form of association rules, clustering, classification and correlation suitable for data characteristics. They concluded that the decision maker must be a practicing statistician to gain a greater understanding of their business to help reduce fraud, improve underwriting and enhance risk management.

Kalyani (2012) exposed in his study several major data techniques that can be used in data mining such as clustering, association, classification, sequential patterns and prediction, etc. These techniques can help in finding the patterns to predict future trends in businesses to get bigger.

Moin and Ahmed (2012), in their paper, give an overview of the concept of data mining and highlights the applications of data mining to improve the performance in the banking sector.

Petre (2013) focuses in her study on presenting the applications of data mining in the business environment. Also, her paper presents the main business areas which can benefit from the use of data mining tools: retail, banking and insurance. Peter concluded, that the architecture proposed for the data mining solution for the business environment would improve the efficiency of the company, by providing valuable decision making knowledge to minimize operating costs and gain competitive advantage.

Ramageri and Desai (2013) explain in their study, how data mining can be applied, and be useful, in the retail industry to make better business decisions. They proved that in retail industry data mining techniques can be deployed for market campaigns, to target profitable customers using reward based points. By doing so, the retail industry will make a better profit, resist and will be more successful in this competitive market if adopted data mining technology for market campaigns. Pulakkazy and Balan (2013) study reveals about data mining techniques used in the banking sector. Using this technique the decision making will become easier and faster. Banks are using data mining in marketing, credit risk management, detection of money laundering, liquidity management, investment banking, and fraud detection. The identified patterns help the bank predict future proceedings.

Jayarsee and Balan (2013) show the significance of data mining technologies and its advantages in the banking and financial sectors.

Chitra and Subashini (2013) in their study analyze the data mining techniques and its applications in banking sector like customer retention, automatic credit approval, fraud prevention and detection, acquiring new customer, provide segment based products, marketing and risk management. At last concludes that data mining techniques are very useful to the banking sector, so the decision-making process becomes very fast.

Raju et al. (2014) provide a critique of the concept of data mining and customer relationship management in organized banking and retail industries. Their study discusses various tasks and applications of data mining in 
different sectors. They concluded that its applications in different areas as analyzing medical outcomes, detecting credit card fraud, predicting customer purchase behavior, predicting the personal interests of Web users, etc. have been very successful. Also, the retail industry is becoming aware that data mining techniques could give them a competitive advantage. Also, they confirmed that the actors of this industry have realized the utility of data mining and its significant importance in their decision-making process and derive considerable competitive advantage to withstand competition in future in addition to immense benefit.

Islam and Habib (2015) attempt to build up a model to predict prospective business sectors in retail banking. To achieve this, data mining techniques are adopted to analyze the challenging issues, where pruned decision tree classification technique has been used to develop the model.

Hamid and Ahmed (2016) use data mining to develop a predictive model for classifying loan risk in the banking sector. This model can be used to predict and classify the applications of loans that are introduced by the customers to good or bad loan by investigating customer behaviors and previous pay back credit.

Sudhakar and Reddy (2016) give an effective prediction model for the bankers that help them predict credible customers who have applied for a loan. Decision Tree Induction Data Mining Algorithm is applied to predict the attributes relevant to credibility.

Soumya and Deepika (2016) present data mining with predictive analytics for financial applications and explores methodologies and techniques in data mining area combined with predictive analytics for application-driven results for financial data. They concluded that financial services institutions use predictive analytics to segment customers and predict which ones will react well to cross-selling promotions. Predictive analytics is ideal for classifying which customers are likely to respond to offers for additional products and services, allowing banks to achieve profitability in the near term.

Preethi and Vijayalakshmi (2017) analyze the various data mining techniques and concepts that can be applied to the banking sector to enhance its performance. At last, concludes that bank will obtain a massive profit if they implement data mining in their process of data and decisions.

\section{Research Problem and Hypotheses:}

Drawing from the previous studies, the researchers have the following questions in mind:

- To what extent do banks in Lebanon have interest to work using data mining systems to have positive effects on the bank operations?

- Are there differences of statistical significance among the sample in implementing IT in running the banking operations which refer to the difference in years of experience, job level, and academic qualification?

Based on the questions, the researchers have the following hypotheses to discuss and to be accepted or rejected:

$\mathbf{H}_{1}$ : There is interest in implementing concepts of data mining technology in managing operations at Lebanese banks.

$\mathbf{H}_{\mathbf{0 2}}$ : There is no difference of statistical significance among the respondents' opinions about implementing concepts of data mining technology in managing operations at Lebanese banks, as relative to difference in experience, job level or academic qualification.

\section{Theoretical Framework}

\subsection{Data Mining}

Data mining has become a modern concept in support of successful decision-making systems in modern-day business organizations (Michael et al., 2000). There emerged the need for a practical phase to conclude specifications and relations between given information, in addition to presenting information which was not popular previously in the domain of traditional information systems. This is called data mining which provides new roles to previous one where it supplies information and wide knowledge which help in making better decisions. This includes the following (Turban \& Leinder, 2008):

- Creating Knowledge: Knowledge systems supply employees in the cognitive domain with graphs, analysis, means to manage documents, in addition to access to internal and external sources of information and knowledge.

- Discovering and Codifying Knowledge: Artificial Intelligence Systems have provided the possibility of integrating experience in order to indentify relations and patterns within large amount of information. Decision Support Systems can analyze a large data-base and discover new information. 
- Sharing Knowledge: Collaborative systems can help employees access simultaneously and work on the same document from distinct locations to coordinate their various activities.

- Distributing Knowledge: Information and communication systems can supply documents and other means of information and distribute them among employees in the information sector to link offices to other business units inside and outside the organization.

Consequently, features which data mining support with - such as providing accurate information quickly- show the importance of this technique in decision-making. Most important features of data mining include (Hussein, 2004):

a) Helping the decision-maker enhance association among different divisions of an organization.

b) It facilitates tackling modern information technology and helps valuate the efficiency and productivity of subsidiary information systems through providing accurate information.

c) It helps the efficient use of available data sources and plan to improve available accounting and banking systems.

d) It helps disclose the organization's ability and capacity to evolve and be in accord with development and its needs to improve information systems of technical and human resources.

e) It enables decision-makers to plan for continual testing and problem-finding, in addition to control over data information files necessary for decisions.

f) It assists the decision-makers in whatever they need to make decisions which enhance work, accomplish tasks and facilitate procedures.

Consequently, the information technology environment has created a novel concept which was rarely recognized before because of the great current need for information and for all forms of communication and relation between financial and economic activities. Great need for search engines emerged to seek a lot of information as a result of progress in knowledge concepts; thus, the following needs were urgent:

\section{Administrative Level Needs}

Accounting and banking information systems help all administrative levels by providing information necessary to manage their work. Following are the administrative levels (Kassem, 2004):

1) The Strategic Level Administration: The higher level needs information for long-term planning and specifying goals to be achieved.

2) Management Level Administration: These are middle level management which use the information for medium-term planning and for changing the goals to working programs and specifying the financial and human costs for each of the goals.

3) Knowledge Level Administration: This class of administration uses the information for short term planning and in changing plans and programs to detailed agendas which involve employees who work in data, knowledge and information.

4) Operational Level: This is the main basis for an organization's actions which include managing operations (Dahrawi, 2007).

\section{Systems Relations}

Accounting and banking information systems interact with a large sum of individuals who are sharing in managing the systems' affairs. Most important domains of this interaction is as follows (Helms \& Mancino, 1998):

A. Category of employees involved in the communication: These vary according to the quality of information that they need to manage and accomplish their jobs.

B. Communication through the systems: Banking and accounting systems rely on a number of procedures and activities which are influenced by the information technology environment.

C. Communication with other systems: Most operating systems receive input from other systems. Thus, it is vitally important to specify the procedures and conditions under which the connection is made.

D. Finding search engines among a number of systems: Information systems interact within a greater system and there should be a clear relation whose results should be in the data basis which can satisfy the requirements of all information services which are designed for different purposes and intended for 
different users.

\subsection{Information Production}

Accounting can be considered as an information system which is specific to identifying, measuring and producing enough information about the economic organization which can be used in valuation and decision-making by users of this information (Romney \& Steinbart, 2003). Consequently, the financial events in the life of any individual or organization can be followed up in a way that enables the individual or organization to disclose the financial position and the activities done for everyone who is interested in that individual or organization.

Producing information through accounting systems is considered necessarily important which should comply with a group of standards which guarantees its quality as the outputs of accounting information systems are important to get the greatest value from them within the least time and effort. Tackling these outputs should be in accord with the following standards (Kashef, 2000):

A. Standards of using information: Using outputs of banking and accounting information system is a requirement within and outside the organization; therefore, the process of producing information is two types as follows:

- Information necessary for use in the bank: It is included in the reports presented to the decision-makers and managers.

- Information for use outside the bank: It includes reports presented to parties of interest in the activities of the bank.

B. Standards of size of the produced information: The size of the required information affects the method used to obtain it. Thus, if the required information is much, factors of producing it typed is affected by speed of getting it accessible and speed of the means used in producing it such as monitors, printers, network, etc.

C. Standards of quality of produced information: Knowledge of how to use information helps in determining the level of quality required, such as the case when the managers require certain information to make a decision, the level of quality of presented information should reach the point of zero error (Marakas, 2003).

D. Standards of costs of produced information: Cost of produced information in accounting information systems is affected with the time required to produce it or the level of quality required since it requires some high cost technology (Ener, 1992).

\subsection{Data Warehousing}

Information technology has created new roles for accounting information systems which enable them to tackle the information in ways that are different from traditional ways. Following are some:

a. Data Storage: Data passes through all stages of gathering and producing information which leads to the final result since one system's input is another system's output (Marakas, 2003). Thus, gathering information from different sources within the bank and changing it to homogeneous data which helps in decision-making enables everyone of interest to access the information which is in a data-base waiting to be processed then stored in the data-base to be used later.

b. Storing data to meet quality standards: Inputs of accounting and banking information technology is important for producing proper information that meets its required characteristics since tackling information systems inputs starts with gathering tasks and activities necessary to obtain data and getting it to the first step in the systems (Kassem, 2004).

c. Storing data to meet the needs of users: The need for information requires storing data to guarantee coordination among activities and distribution among employees and other people of interest to reduce time and present it properly, correctly and inexpensively (Enderson \& William, 2002).

\section{Methodology}

The researchers adopted the qualitative and descriptive approach, utilizing an empirical study. The researchers developed a questionnaire to collect necessary data for the study to be analyzed using SPSS method. The questionnaire is of about 30 items to be distributed to a population of commercial banks in Lebanon. As for the sample surveyed, it includes personnel who work in Information Technology (IT), people concerned in creating accounting and banking systems, and people who work in key banking operations. The researchers distributed 160 copies of the questionnaire in 50 banks and their branches operating in Lebanon. 


\section{Procedures and Methods}

\subsection{Population and Sample}

Since the topic of the research is "Impact of Application of Data Mining in the Lebanese Banking Sector", the society of the study was employees of nine banks operating in Lebanon, by varying the banks and their regions of operation and varying employees as to their different positions and tasks required from them in addition to their authorities and responsibilities. In the empirical part of the study, the researchers utilized a questionnaire which is an important source of information necessary for the study.

The total number of questionnaires distributed on the sample was 160 . The researchers retrieved 155,150 of which were valid for the study. This sample represents the society of the study and its general inclination.

Table 1. Sample distribution

\begin{tabular}{ccc}
\hline Career level & Frequency & Percent \% \\
\hline Manager & $\mathbf{9}$ & $\mathbf{6}$ \\
Head of department & $\mathbf{4 4}$ & $\mathbf{2 9 . 3}$ \\
Employee & $\mathbf{9 7}$ & $\mathbf{6 4 . 7}$ \\
Total : N & $\mathbf{1 5 0}$ & $\mathbf{1 0 0 . 0}$ \\
\hline
\end{tabular}

\subsection{Instrumentation}

Based on the literature review, an informal discussion with high leveled banking experts was conducted, after which the researchers constructed a three-point scale questionnaire and asked managers of banks, heads of departments and employees to respond to the items as shown in the table below:

Table 2. Mean

\begin{tabular}{cc}
\hline Weighted average & Mean \\
\hline $1-1.66$ & High \\
$1.67-2.33$ & Medium \\
$2.34-3$ & Low \\
\hline
\end{tabular}

Findings of the current study show the reliability of the scale used, Cronbach's Alfa was calculated using SPSS to check the accuracy of the sample's responses.

It is clear from the above table that Cronbach's Alfa is 0.969 (96.9\%) in general for the questions, which is a strong sign of reliability.

Table 3.Cronbach's Alpha

\begin{tabular}{cccc}
\hline Domain & Variables & Cronbach's Alpha Based on Standardized Items & Cronbach's Alfa \\
\hline First & $\mathbf{8}$ & $\mathbf{0 . 9 8 3}$ & $\mathbf{0 . 9 7 1}$ \\
Second & $\mathbf{8}$ & $\mathbf{0 . 9 6 7}$ & $\mathbf{0 . 9 6 8}$ \\
Third & 7 & $\mathbf{0 . 9 5 4}$ & $\mathbf{0 . 9 5 8}$ \\
Fourth & 7 & $\mathbf{0 . 9 7 7}$ & $\mathbf{0 . 9 7 9}$ \\
Fifth & 7 & $\mathbf{0 . 9 8 8}$ & $\mathbf{0 . 9 8 7}$ \\
Sixth & $\mathbf{7}$ & $\mathbf{0 . 9 5 7}$ & $\mathbf{0 . 9 5 9}$ \\
All Domains & $\mathbf{4 4}$ & $\mathbf{0 . 9 6 5}$ & $\mathbf{0 . 9 6 9}$ \\
\hline
\end{tabular}

\section{Testing and Analyzing the Hypotheses}

7.1 First Domain: The Extent of Attention for Knowledge Work Environment Using Information Technology (IT)

Table 4.The extent of attention for knowledge work environment using information technology (IT).

\begin{tabular}{llccccc}
\hline \multicolumn{1}{c}{ Items } & High & Medium & Low & Sig.(2-tailed) & Std.deviation \\
\hline Q1 & $\begin{array}{l}\text { Using IT systems has changed the direct work environment } \\
\text { toward increasing its efficiency. }\end{array}$ & 30.7 & 45.3 & 24.0 & 0.001 & 1.145 \\
Q2 $\quad \begin{array}{l}\text { Using IT has changed the culture of the bank toward } \\
\text { internal and external clients. }\end{array}$ & 34.7 & 26.7 & 38.6 & 0.000 & 1.123 \\
Q3 $\quad \begin{array}{l}\text { Using advanced algorithms has made positive changes in } \\
\text { the service domains which respond to a client's needs. }\end{array}$ & 42 & 22.7 & 35.3 & 0.000 & 1.135 \\
\hline
\end{tabular}




\begin{tabular}{|c|c|c|c|c|c|c|}
\hline$\underline{\mathrm{Q}} 4$ & $\begin{array}{l}\text { Using IT has helped in transferring data from the bank and } \\
\text { to it and among its departments and branches. }\end{array}$ & 37.4 & 35.3 & 27.3 & 0.002 & 1.015 \\
\hline Q5 & $\begin{array}{l}\text { The used algorithms help in processing data fast enough to } \\
\text { meet the requirement of clients getting service as they hope. }\end{array}$ & 29.3 & 30.7 & 40 & 0.000 & 1.174 \\
\hline$\underline{\mathrm{Q} 6}$ & $\begin{array}{l}\text { The technological advancement the bank reached achieves } \\
\text { the principle of technological innovation based on a huge } \\
\text { stock of knowledge and applications. }\end{array}$ & 29.3 & 50.7 & 20 & 0.000 & 1.189 \\
\hline Q7 & $\begin{array}{l}\text { Data transfer systems achieve the principle of technological } \\
\text { innovation based on human effort. }\end{array}$ & 38 & 25.3 & 36.7 & 0.002 & 1.041 \\
\hline \multirow[t]{2}{*}{ Q8 } & $\begin{array}{l}\text { Technological innovation leads to devising new ideas in an } \\
\text { organized and convenient framework. }\end{array}$ & 36.7 & 38 & 25.3 & 0.000 & 1.324 \\
\hline & Total & $34.75 \%$ & $34.33 \%$ & $30.91 \%$ & 0.0006 & 1.120 \\
\hline
\end{tabular}

The above table 4 shows that the answers of $76 \%$ of the sample were high and medium that "using IT systems has changed the direct work environment toward increasing its efficiency", while 34\% responded as low. The table also shows that $61.4 \%$ of the sample responded high and medium that "using IT has changed the culture of the bank toward internal and external clients", while $38.6 \%$ were low. The table also shows that answers of $64.7 \%$ of the sample were high and medium that "using advanced algorithms has made positive changes in the service domains which respond to a client's needs", while $35.3 \%$ were low. The table also shows that answers of $72.6 \%$ of the sample were high and medium that "using IT has helped in transferring data from the bank and to it and among its departments and branches", while $27.2 \%$ were low. It is also evident from the above table that the answers of $60 \%$ of the sample were high and medium that "the used algorithms help in processing data fast enough to meet the requirement of clients getting service as they hope", while $20 \%$ were low. The table also shows that $80 \%$ of the sample responded high and medium that "the technological advancement the bank reached achieves the principle of technological innovation based on a huge stock of knowledge and applications", while $20 \%$ were low. It is also evident from the above table that the answers of $63.3 \%$ of the sample were high and medium that "the used algorithms help in processing data fast enough to meet the requirement of clients getting service as they hope", while $36.7 \%$ were low. The table also shows that answers of $74.7 \%$ of the sample were high and medium that "technological innovation leads to devising new ideas in an organized and convenient framework", while $25.3 \%$ were low.

7.2 Second Domain: The Extent of Attention for Enhancing Knowledge Systems Using Evolvement of Search Systems

Table 5. The extent of attention for enhancing knowledge systems using evolvement of search systems

\begin{tabular}{|c|c|c|c|c|c|c|}
\hline & Items & High & Medium & Low & $\begin{array}{c}\text { Sig. } \\
\text { (2-tailed) }\end{array}$ & $\begin{array}{c}\text { Std. } \\
\text { deviation }\end{array}$ \\
\hline$\underline{\mathrm{Q} 1}$ & $\begin{array}{l}\text { The bank realizes knowledge of the field to be worked on by attaining necessary, } \\
\text { scientific and technical data depending on internal and external sources of data. }\end{array}$ & 45.3 & 31.4 & 23.3 & 0.001 & 1.165 \\
\hline$\underline{\mathrm{Q} 2}$ & $\begin{array}{l}\text { The bank gets the verbal and written data which is available in data banks using } \\
\text { proper techniques. }\end{array}$ & 48 & 27.4 & 24.6 & 0.000 & 1.087 \\
\hline$\underline{\mathrm{Q} 3}$ & $\begin{array}{l}\text { The bank is capable of valuation based on the ability to discover risks and } \\
\text { threats. }\end{array}$ & 50.7 & 26 & 23.3 & 0.003 & 1.062 \\
\hline$\underline{\mathrm{Q} 4}$ & $\begin{array}{l}\text { The bank has the ability to know the modern technological potentials which } \\
\text { enables it to get verbal and written data which is available in data banks. }\end{array}$ & 40.1 & 38.6 & 21.3 & 0.000 & 1.115 \\
\hline Q5 & $\begin{array}{l}\text { The bank has the ability to evaluate the available potentials and the possibility of } \\
\text { using them externally. }\end{array}$ & 34.1 & 39.3 & 26.6 & 0.005 & 1.274 \\
\hline Q6 & $\begin{array}{l}\text { The bank has the ability to integrate all theoretical and practical knowledge } \\
\text { elements to find something new, the ability to integrate various technological } \\
\text { resources. }\end{array}$ & 32.7 & 38 & 29.3 & 0.000 & 1.221 \\
\hline$\underline{\mathrm{Q} 7}$ & $\begin{array}{l}\text { The bank realizes that work or research requires innovation, hard work and focus } \\
\text { to go beyond what is available relying on present knowledge. }\end{array}$ & 44 & 36.7 & 19.3 & 0.001 & 1.096 \\
\hline$\underline{\mathrm{Q} 8}$ & $\begin{array}{l}\text { The bank realizes that developing communication technology is a must and } \\
\text { requires innovating the used technology on the part of economic business } \\
\text { organizations to adapt with society requirements. }\end{array}$ & 30.1 & 28.6 & 41.3 & 0.001 & 1.371 \\
\hline & Total & $40.56 \%$ & $33.21 \%$ & $26.12 \%$ & 0.0013 & 1.143 \\
\hline
\end{tabular}


The above table 5 shows that the answers of $76.7 \%$ of the sample were high and medium that "the bank realizes knowledge of the field to be worked on by attaining necessary, scientific and technical data depending on internal and external sources of data", while $23.3 \%$ responded as low. It is evident from the table that $75.4 \%$ that "the bank gets the verbal and written data which is available in data banks using proper techniques", while $24.6 \%$ were low.

The table also shows that the answers of $76.7 \%$ of the sample were high and medium that "the bank is capable of valuation based on the ability to discover risks and threats", while $23.3 \%$ responded as low. It is evident from the table that $78.7 \%$ that "the bank has the ability to know the modern technological potentials which enables it to get verbal and written data which is available in data banks", while $21.3 \%$ were low. The above table also shows that the answers of $73.4 \%$ of the sample were high and medium that "the bank has the ability to evaluate the available potentials and the possibility of using them externally", while $26.6 \%$ responded as low. The above table shows that the answers of $70.7 \%$ of the sample were high and medium that "the bank has the ability to integrate all theoretical and practical knowledge elements to find something new, the ability to integrate various technological resources", while $29.3 \%$ responded as low. It is evident from the table that $80.7 \%$ that "the bank realizes that work or research requires innovation, hard work and focus to go beyond what is available relying on present knowledge", while $19.3 \%$ were low. The above table also shows that the answers of $73.4 \%$ of the sample were high and medium that "the bank has the ability to evaluate the available potentials and the possibility of using them externally", while $26.6 \%$ responded as low. The above table also shows that the answers of $58.6 \%$ of the sample were high and medium that "the bank realizes that developing communication technology is a must and requires innovating the used technology on the part of economic business organizations to adapt with society requirements", while $41.3 \%$ responded as low.

\subsection{Third Domain: The Extent of Attention Given to Search Systems as a Tool to Exchange Knowledge with External Environment}

Table 6. The extent of attention given to search systems as a tool to exchange knowledge with external environment

\begin{tabular}{|c|c|c|c|c|c|c|}
\hline & Items & High & Medium & Low & $\begin{array}{c}\text { Sig. } \\
\text { (2-tailed) }\end{array}$ & $\begin{array}{c}\text { Std. } \\
\text { deviation }\end{array}$ \\
\hline$\underline{\mathrm{Q} 1}$ & $\begin{array}{l}\text { The bank works as an open system where it relies on the elements } \\
\text { available in the external environment, with its various frames, in its inputs. }\end{array}$ & 49.3 & 22.1 & 28.6 & 0.000 & 1.174 \\
\hline$\underline{\mathrm{Q} 2}$ & $\begin{array}{l}\text { The bank is concerned with monitoring and following up the external } \\
\text { surrounding to adapt with it, and does its best to incorporate with it to } \\
\text { lessen its negative consequences. }\end{array}$ & 45.3 & 27.7 & 27.3 & 0.001 & 1.417 \\
\hline$\underline{\mathrm{Q} 3}$ & $\begin{array}{l}\text { The bank perceives the importance of adopting modern concepts in success } \\
\text { of decision support systems in modern business organizations and in } \\
\text { providing data which helps making decisions. }\end{array}$ & 44.1 & 34.6 & 21.3 & 0.000 & 1.145 \\
\hline$\underline{\mathrm{Q} 4}$ & $\begin{array}{l}\text { The bank recognizes the need for a procedural stage to extract relations and } \\
\text { specifications from data and present new data strange to traditional work } \\
\text { systems. }\end{array}$ & 39.3 & 38.7 & 22 & 0.002 & 1.114 \\
\hline Q5 & $\begin{array}{l}\text { The bank realizes that the requirements of the external environment in the } \\
\text { form of used systems have impelled a new environment toward practicing } \\
\text { the knowledge role as integrated systems to whom new roles additional to } \\
\text { their traditional roles are added, which supply new data and vast } \\
\text { knowledge which helps in taking good decisions. }\end{array}$ & 32.6 & 40.1 & 27.3 & 0.000 & 1.126 \\
\hline Q6 & $\begin{array}{l}\text { The bank realizes the importance of helping service recipients to } \\
\text { understand services that are based on correct available data about them. }\end{array}$ & 33.3 & 37.4 & 29.3 & 0.002 & 1.347 \\
\hline Q7 & $\begin{array}{l}\text { The bank realizes the importance of service recipients understanding } \\
\text { services designed to fulfill their needs, being concerned with accounting } \\
\text { and banking data systems because of the results reflected in the services } \\
\text { they receive. }\end{array}$ & 43.3 & 37.4 & 19.3 & 0.004 & 1.412 \\
\hline & Total & $41.01 \%$ & $33.87 \%$ & $25.01 \%$ & 0.0012 & 1.152 \\
\hline
\end{tabular}

The above table 6 also shows that the answers of $71.4 \%$ of the sample were high and medium that "the bank works as an open system where it relies on the elements available in the external environment, with its various frames, in its inputs", while $28.6 \%$ responded as low. The table also shows that the answers of $72.7 \%$ of the 
sample were high and medium that "the bank is concerned with monitoring and following up the external surrounding to adapt with it, and does its best to incorporate with it to lessen its negative consequences", while $27.3 \%$ responded as low. The table also shows that the answers of $78.7 \%$ of the sample were high and medium that "the bank perceives the importance of adopting modern concepts in success of decision support systems in modern business organizations and in providing data which helps making decisions", while $21.3 \%$ responded as low. The table also shows that the answers of $78 \%$ of the sample were high and medium that "the bank recognizes the need for a procedural stage to extract relations and specifications from data and present new data strange to traditional work systems", while $22 \%$ responded as low. The table also shows that the answers of $72.7 \%$ of the sample were high and medium that "the bank realizes that the requirements of the external environment in the form of used systems have impelled a new environment toward practicing the knowledge role as integrated systems to whom new roles additional to their traditional roles are added, which supply new data and vast knowledge which helps $n$ taking good decisions", while $27.3 \%$ responded as low. The table also shows that the answers of $70.7 \%$ of the sample were high and medium that "the bank realizes the importance of helping service recipients to understand services that are based on correct available data about them", while 29.3\% responded as low. The table also shows that the answers of $80.7 \%$ of the sample were high and medium that "the bank realizes the importance of service recipients understanding services designed to fulfill their needs, being concerned with accounting and banking data systems because of the results reflected in the services they receive", while $19.3 \%$ responded as low.

7.4 Fourth Domain: The Extent of Attention Given to Search Systems as Tools of Knowledge Exchange with the Internal Environment

Table 7. The extent of attention given to search systems as tools of knowledge exchange with the internal environment

\begin{tabular}{|c|c|c|c|c|c|c|}
\hline & Items & High & Medium & Low & $\begin{array}{c}\text { Sig. } \\
\text { (2-tailed) }\end{array}$ & $\begin{array}{c}\text { Std. } \\
\text { Deviation }\end{array}$ \\
\hline Q1 & $\begin{array}{l}\text { Upper-level managements use produced data for long-term planning, } \\
\text { drawing general policies and goals, and specifying goals to be achieved. }\end{array}$ & $45 \%$ & $33.5 \%$ & $21.5 \%$ & 0.000 & 1.195 \\
\hline$\underline{\mathrm{Q} 2}$ & $\begin{array}{l}\text { Mid-level managements use produced data for mid-term planning, } \\
\text { interpreting goals to work schedules, and specifying material and human } \\
\text { resources necessary for specific goals. }\end{array}$ & $44 \%$ & $41 \%$ & $15 \%$ & 0.000 & 1.241 \\
\hline$\underline{\mathrm{Q} 3}$ & $\begin{array}{l}\text { Supervisory managements use produced data for short-term planning and } \\
\text { changing plans into detailed programs incorporating those who work with } \\
\text { data, information and knowledge. }\end{array}$ & $39 \%$ & $37 \%$ & $24 \%$ & 0.000 & 1.147 \\
\hline$\underline{\mathrm{Q}}$ & $\begin{array}{l}\text { 4- Data mining helps system users find solutions for their problems, } \\
\text { understand using systems, their inputs processes and outputs; and } \\
\text { consequently, the form of reports they will sign and adopt. }\end{array}$ & $34 \%$ & $31 \%$ & $35 \%$ & 0.000 & 1.174 \\
\hline$\underline{\mathrm{Q} 5}$ & $\begin{array}{l}\text { Data mining helps programmers and system analysts know how their bank } \\
\text { works and supplies them with what they need to understand its goals, } \\
\text { function of actions in it and to solve problems they are responsible for. }\end{array}$ & $40 \%$ & $22.4 \%$ & $37.6 \%$ & 0.001 & 1.185 \\
\hline Q6 & $\begin{array}{l}\text { Data mining helps find ability of communication among employees } \\
\text { concerned with performing services clearly, whose result is the well-being } \\
\text { of system operations planned for use at the bank and for fast, efficient } \\
\text { processing. }\end{array}$ & $37.5 \%$ & $26.4 \%$ & $36.1 \%$ & 0.000 & 1.365 \\
\hline Q7 & $\begin{array}{l}\text { The management helps in reaching the results required from accounting, } \\
\text { banking and search systems to solve management and bank problems and in } \\
\text { noting the importance of the goals to be achieved at the bank. }\end{array}$ & $33.8 \%$ & $30.4 \%$ & $35.8 \%$ & 0.001 & 1.741 \\
\hline & Total & $39.04 \%$ & $31.67 \%$ & $29.28 \%$ & 0.000 & 1.204 \\
\hline
\end{tabular}

The above table 7 shows that the answers of $78.5 \%$ of the sample were high and medium that "upper-level managements use produced data for long-term planning, drawing general policies and goals, and specifying goals to be achieved", while $21.5 \%$ responded as low. It is evident from the above table that $85 \%$ that "mid-level managements use produced data for mid-term planning, interpreting goals to work schedules, and specifying material and human resources necessary for specific goals", while $15 \%$ were low. It is also evident from the above table that $76 \%$ that "supervisory managements use produced data for short-term planning and changing plans into detailed programs incorporating those who work with data, information and knowledge", while $24 \%$ 
were low. The table also shows that the answers of $65 \%$ of the sample were high and medium that "data mining helps system users find solutions for their problems, understand using systems, their inputs processes and outputs; and consequently, the form of reports they will sign and adopt", while $35 \%$ responded as low. The table also shows that the answers of $62.4 \%$ of the sample were high and medium that "data mining helps programmers and system analysts know how their bank works and supplies them with what they need to understand its goals, function of actions in it and to solve problems they are responsible for", while $37.6 \%$ responded as low. The table also shows that the answers of $63.9 \%$ of the sample were high and medium that "data mining helps find ability of communication among employees concerned with performing services clearly, whose result is the well-being of system operations planned for use at the bank and for fast, efficient processing", while $36.1 \%$ responded as low. It is also evident from the above table that $64.2 \%$ that "the management helps in reaching the results required from accounting, banking and search systems to solve management and bank problems and in noting the importance of the goals to be achieved at the bank", while $35.8 \%$ were low.

7.5 Fifth Domain: The Extent of Attention in Search Systems and Mining as a Supportive Tool to Manage Knowledge

Table 8. The Extent of attention in search systems and mining as a supportive tool to manage knowledge

\begin{tabular}{|c|c|c|c|c|c|c|}
\hline & Items & High & Medium & Low & $\begin{array}{c}\text { Sig. } \\
\text { (2-tailed) }\end{array}$ & $\begin{array}{c}\text { Std. } \\
\text { deviation }\end{array}$ \\
\hline$\underline{\mathrm{Q} 1}$ & $\begin{array}{l}\text { Data mining is an impelling need to find knowledge among knowledge } \\
\text { information systems, necessary to supply knowledge workers with graphs, } \\
\text { analysis, communications and means of managing documents. }\end{array}$ & $32.5 \%$ & $33.8 \%$ & $33.7 \%$ & 0.000 & 1.165 \\
\hline$\underline{\mathrm{Q} 2}$ & $\begin{array}{l}\text { Data mining is an impelling need to supply knowledge through knowledge } \\
\text { information systems which help in reaching internal and external sources of } \\
\text { information and knowledge. }\end{array}$ & $29.6 \%$ & $33.9 \%$ & $36.5 \%$ & 0.001 & 1.112 \\
\hline$\underline{\mathrm{Q} 3}$ & $\begin{array}{l}\text { Data mining was a result of discovering knowledge supplied by artificial } \\
\text { intelligence systems in the possibility of devising and fusing alternatives to } \\
\text { find patterns and relationships in mounds of data. }\end{array}$ & $45.9 \%$ & $25.5 \%$ & $28.6 \%$ & 0.000 & 1.274 \\
\hline$\underline{\mathrm{Q}}$ & $\begin{array}{l}\text { The bank applies the required decision support systems related to analyzing } \\
\text { large data bases and discover new knowledge. }\end{array}$ & $39.9 \%$ & $22.4 \%$ & $37.7 \%$ & 0.001 & 1.415 \\
\hline$\underline{\text { Q5 }}$ & $\begin{array}{l}\text { Data mining requires classifying knowledge to find new patterns and } \\
\text { relationships resulting from analysis of large data bases which can also } \\
\text { discover new knowledge. }\end{array}$ & $35.1 \%$ & $41.3 \%$ & $23.6 \%$ & 0.000 & 1.195 \\
\hline Q6 & $\begin{array}{l}\text { Data mining is performed through sharing knowledge, based on collaborative } \\
\text { cooperation can help workers reach and work on the same document from } \\
\text { various positions and coordinate their various activities. }\end{array}$ & $29.4 \%$ & $26.8 \%$ & $43.8 \%$ & 0.000 & 1.108 \\
\hline \multirow[t]{2}{*}{ Q7 } & $\begin{array}{l}\text { Data mining is concerned with distribution of knowledge through office } \\
\text { systems and communication tools which can supply documents and other } \\
\text { forms of information, then circulate them among knowledge and information } \\
\text { workers to link offices with other work units inside and outside the bank. }\end{array}$ & $50.7 \%$ & $21.4 \%$ & $27.9 \%$ & 0.000 & 1.117 \\
\hline & Total & $\begin{array}{c}37.42 \\
\%\end{array}$ & $29.35 \%$ & $\begin{array}{c}33.42 \\
\%\end{array}$ & 0.000 & 1.129 \\
\hline
\end{tabular}

It is evident from the above table 8 that $66.3 \%$ that "data mining is an impelling need to find knowledge among knowledge information systems, necessary to supply knowledge workers with graphs, analysis, communications and means of managing documents", while $33.7 \%$ were low. It is also evident from the above table that $63.5 \%$ that "data mining is an impelling need to supply knowledge through knowledge information systems which help in reaching internal and external sources of information and knowledge", while $36.5 \%$ were low. The table also shows that the answers of $71.4 \%$ of the sample were high and medium that "data mining was a result of is covering knowledge supplied by artificial intelligence systems in the possibility of devising and fusing alternatives to find patterns and relationships in mounds of data", while $28.6 \%$ responded as low. The table also shows that the answers of $62.3 \%$ of the sample were high and medium that "the bank applies the required decision support systems related to analyzing large data bases and discover new knowledge", while 37.7\% responded as low. It is also evident from the above table that $63.5 \%$ of the sample were high and medium that "data mining is an impelling need to supply knowledge through knowledge information systems which help in reaching internal and external sources of information and knowledge", while 36.5\% were low. It is also evident 
from the above table that $76.4 \%$ of the sample were high and medium that "data mining requires classifying knowledge to find new patterns and relationships resulting from analysis of large data bases which can also discover new knowledge", while $23.6 \%$ were low. The table also shows that the answers of $56.2 \%$ of the sample were high and medium that "data mining is performed through sharing knowledge, based on collaborative cooperation can help workers reach and work on the same document from various positions and coordinate their various activities", while $43.8 \%$ responded as low. The table also shows that the answers of $72.1 \%$ of the sample were high and medium that "data mining is concerned with distribution of knowledge through office systems and communication tools which can supply documents and other forms of information, then circulate them among knowledge and information workers to link offices with other work units inside and outside the bank", while $27.9 \%$ responded as low.

\subsection{Sixth Domain: The Extent of Attention in Search Systems and Mining as a Decision Support Tool}

Table 9. The extent of attention in search systems and mining as a decision support tool

\begin{tabular}{|c|c|c|c|c|c|c|}
\hline & Items & High & Medium & Low & $\begin{array}{c}\text { Sig. } \\
\text { (2-tailed) }\end{array}$ & $\begin{array}{c}\text { Std. } \\
\text { deviation }\end{array}$ \\
\hline$\underline{\mathrm{Q} 1}$ & $\begin{array}{l}\text { The search systems used requires speed since required documentary } \\
\text { procedures for information and servers are much faster when using } \\
\text { computers, especially in restoring data. }\end{array}$ & $36.6 \%$ & $32.8 \%$ & $30.6 \%$ & 0.000 & 1.108 \\
\hline Q2 & $\begin{array}{l}\text { The search systems used are accurate to ensure accuracy and avoid } \\
\text { errors, whose possibilities are more in traditional, manual systems } \\
\text { than in computerized systems. }\end{array}$ & $37.8 \%$ & $24.7 \%$ & $37.5 \%$ & 0.000 & 1.103 \\
\hline$\underline{\text { Q3 }}$ & $\begin{array}{l}\text { The search systems used help save effort in dealing with information } \\
\text { and its sources, processing it, storing it and managing it; and in } \\
\text { restoring data and sources to use them by researchers and others. }\end{array}$ & $41.7 \%$ & $33.8 \%$ & $24.5 \%$ & 0.000 & 1.584 \\
\hline$\underline{\mathrm{Q}}$ & $\begin{array}{l}\text { The search systems used help in saving massive amounts of data since } \\
\text { data bases and warehouses are increasingly large compared to the } \\
\text { huge potentials of electronic means of storing. }\end{array}$ & $42.3 \%$ & $22.2 \%$ & $35.5 \%$ & 0.000 & 1.962 \\
\hline$\underline{\mathrm{Q} 5}$ & $\begin{array}{l}\text { The search systems used incorporate available alternatives in } \\
\text { restoring data and using it better and on a wider scale than traditional } \\
\text { systems. }\end{array}$ & $29.9 \%$ & $27.8 \%$ & $42.3 \%$ & 0.000 & 1.107 \\
\hline$\underline{\mathrm{Q} 6}$ & $\begin{array}{l}\text { Most operation systems receive inputs from other systems, sent as } \\
\text { outputs of the latter, in which conditions and procedures of } \\
\text { communication between them are established. }\end{array}$ & $53.2 \%$ & $31.1 \%$ & $15.7 \%$ & 0.000 & 1.147 \\
\hline Q7 & $\begin{array}{l}\text { The bank realizes that outputs of search systems may include critical } \\
\text { information which depends on time and size of the information sent } \\
\text { and gives attention to specify requirements of reaching this } \\
\text { information in due time among these search systems. }\end{array}$ & $44 \%$ & $23 \%$ & $33 \%$ & 0.000 & 1.162 \\
\hline & Total & $40.71 \%$ & $28 \%$ & $31.28 \%$ & 0.000 & 1.249 \\
\hline
\end{tabular}

It is evident from the above table 9 that $69.4 \%$ of the sample were high and medium that "the search systems used requires speed since required documentary procedures for information and servers are much faster when using computers, especially in restoring data", while $30.6 \%$ were low. The table shows that the answers of $62.5 \%$ of the sample were high and medium that "the search systems used are accurate to ensure accuracy and avoid errors, whose possibilities are more in traditional, manual systems than in computerized systems", while $37.5 \%$ responded as low. The table shows that the answers of $75.5 \%$ of the sample were high and medium that "the search systems used help save effort in dealing with information and its sources, processing it, storing it and managing it; and in restoring data and sources to use them by researchers and others", while $24.5 \%$ responded as low. The table shows that the answers of $57.7 \%$ of the sample were high and medium that "the search systems used incorporate available alternatives in restoring data and using it better and on a wider scale than traditional systems", while $42.3 \%$ responded as low. The table also shows that the answers of $84.8 \%$ of the sample were high and medium that "most operation systems receive inputs from other systems, sent as outputs of the latter, in which conditions and procedures of communication between them are established", while $15.7 \%$ responded as low. It is also evident from the above table that $67 \%$ of the sample were high and medium that "the bank realizes that outputs of search systems may include critical information which depends on time and size of the information sent and gives attention to specify requirements of reaching this information in due time among 
these search systems", while $33 \%$ were low.

\section{Testing the Hypotheses}

The research hypotheses were tested using One-Sample T-Test and Analysis of Variance (Anova).

The hypotheses are as follows:

First Hypothesis: There is interest in implementing concepts of data mining technology in managing operations at Lebanese banks.

Second Hypothesis: There is no difference of statistical significance among the respondents' opinions about implementing concepts of data mining technology in managing operations at Lebanese banks, which refer to difference in experience, job level or qualifications.

\subsection{Testing the First Hypothesis}

$\mathrm{H}_{1:}$ There is interest in implementing concepts of data mining technology in managing operations at Lebanese banks.

After analyzing the 44 questions of the second section (6 domains) using One-Sample T-Test, the following results were available:

Table 10. Mean and standard deviation for all items

\begin{tabular}{ccccc}
\hline \multicolumn{5}{c}{ One-Sample Statistics } \\
\hline H1 & N & Mean & Std. Deviation & Std. Error Mean \\
\hline
\end{tabular}

Table 11. Results of one-sample test

\begin{tabular}{|c|c|c|c|c|c|c|}
\hline \multicolumn{7}{|c|}{ One-Sample Test } \\
\hline \multicolumn{7}{|c|}{ Test Value $=1.5$} \\
\hline & \multirow[t]{2}{*}{$\mathrm{t}$} & \multirow[t]{2}{*}{$\mathrm{df}$} & \multirow[t]{2}{*}{ Sig. (2-tailed) } & \multirow[t]{2}{*}{ Mean Difference } & \multicolumn{2}{|c|}{ 95\% Confidence Interval of the Difference } \\
\hline & & & & & Lower & Upper \\
\hline H1 & -37.344 & 149 & 0.000 & $-1.44190-$ & $-1.5182-$ & 1.3656 \\
\hline
\end{tabular}

The above table regarding the first hypothesis shows that the value of the significance (sig) is 0.000 , which is smaller than the significance 0.05 . This means accepting the hypothesis. Consequently:

"There is interest in implementing concepts of data mining technology in managing operations at Lebanese banks."

\subsection{Testing the Second Hypothesis}

$\mathrm{H}_{02}$ : There is no difference of statistical significance among the respondents' opinions about implementing concepts of data mining technology in managing operations at Lebanese banks, which refer to difference in experience, job level or qualifications.

\subsubsection{The Variable 'Experience'}

After analyzing the 44 questions of the second section ( 6 domains) as related to the first hypothesis, the difference between these results and the variable 'experience' in the demographic information as follows:

Table 12. Mean and standard deviation

\begin{tabular}{|c|c|c|c|}
\hline \multicolumn{4}{|c|}{ Confidence Interval for Mean 95\% } \\
\hline Experience (Years) & $\mathbf{N}$ & Mean & Std. Deviation \\
\hline Less than 5 years & 9 & 1.409 & 0.641 \\
\hline 5 to Less than 10 years & 44 & 1.606 & 0.610 \\
\hline 10 to less than 15 years & 49 & 1.861 & 0.531 \\
\hline 15 to less than 20 years & 35 & 2.444 & 0.466 \\
\hline More than 20 years & 13 & 2.101 & 0.485 \\
\hline Total & 150 & 1.916 & 0.634 \\
\hline
\end{tabular}




\subsubsection{One Way Anova}

Table 13. Results of one way anova test

\begin{tabular}{|c|c|c|c|c|c|c|}
\hline Source of Variance & Sum of squares (SS) & df & Mean squares & $\begin{array}{c}\text { F } \\
\text { Calculated }\end{array}$ & $\begin{array}{c}\mathrm{F} \\
\text { Tabulated }\end{array}$ & Sig. \\
\hline Between Groups & $\begin{array}{c}\mathrm{SS}_{\mathrm{B}}= \\
16.894\end{array}$ & $\begin{array}{c}K-1= \\
5-1= \\
4\end{array}$ & $\begin{array}{c}\mathrm{S}_{\mathrm{B}}^{2}= \\
16.89 / 4= \\
4.223\end{array}$ & $\begin{array}{c}\mathrm{S}_{\mathrm{B}}^{2} \mathrm{~S}_{\mathrm{W}}^{2} \\
4.22 / 0.297 \\
=14.207\end{array}$ & & 0.000 \\
\hline Within Groups & $\begin{array}{l}\mathrm{SS}_{\mathrm{W}}= \\
43.107\end{array}$ & $\begin{array}{c}N-K= \\
150-5= \\
145\end{array}$ & $\begin{array}{c}\mathrm{S}_{\mathrm{W}}^{2}= \\
43.10 / 145= \\
0.297\end{array}$ & & $\begin{array}{c}\mathrm{F}_{\alpha(\mathrm{K}-1)} \\
(\mathrm{N}-\mathrm{K}) \\
11.258\end{array}$ & \\
\hline Total & $\begin{array}{c}\mathrm{SS}_{\mathrm{T}}= \\
\mathrm{SS}_{\mathrm{B}}+\mathrm{SS}_{\mathrm{W}}= \\
60.001\end{array}$ & $\begin{array}{c}N-1= \\
150-1= \\
149\end{array}$ & & & & \\
\hline
\end{tabular}

From the above table, it is clear that the value of F Calculated is 14.207 , which is greater than the value of $\mathrm{F}$ Tabulated, which is 11.258 . As a result, the null hypothesis is rejected at $\alpha=0.05$. Consequently:"There is difference of statistical significance among the respondents' opinions about implementing concepts of data mining technology in managing operations at Lebanese banks, which refer to difference in experience, job level or qualifications."

\subsubsection{The Variable 'Job Level'}

After analyzing the 44 questions of the second section ( 6 domains) as related to the first hypothesis, the difference between these results and the variable 'job level' in the demographic information as follows:

Table 14. Mean and standard deviation

\begin{tabular}{cccc}
\hline & \multicolumn{4}{c}{ Confidence Interval for Mean 95\% } & Std. Deviation \\
\hline Job Level & $\mathbf{N}$ & Mean & 0.641 \\
Manager & 9 & 1.409 & 0.608 \\
Head of Department & 44 & 1.584 & 0.557 \\
Employee & 97 & 2.11 & 0.634 \\
Total & 150 & 1.916 & \\
\hline
\end{tabular}

\subsubsection{One Way Anova}

Table 15. Results of one way anova test

\begin{tabular}{|c|c|c|c|c|c|c|}
\hline Source of Variance & Sum of squares (SS) & df & Mean squares & $\begin{array}{c}\mathrm{F} \\
\text { Calculated }\end{array}$ & $\begin{array}{c}\mathrm{F} \\
\text { Tabulated } \\
\end{array}$ & Sig. \\
\hline Between Groups & $\begin{array}{c}\mathrm{SS}_{\mathrm{B}}= \\
10.982\end{array}$ & $\begin{array}{c}K-1= \\
3-1= \\
2\end{array}$ & $\begin{array}{c}\mathrm{S}_{\mathrm{B}}^{2}= \\
10.98 / 2= \\
5.491\end{array}$ & $\begin{array}{c}\mathrm{S}_{\mathrm{B}}{ }^{2} \mathrm{~S}_{\mathrm{W}}{ }^{2} \\
5.49 / 0.333 \\
=16.466\end{array}$ & & 0.000 \\
\hline Within Groups & $\begin{array}{l}\mathrm{SS}_{\mathrm{W}}= \\
49.019\end{array}$ & $\begin{array}{c}N-K= \\
150-3= \\
147\end{array}$ & $\begin{array}{c}\mathrm{S}_{\mathrm{W}}^{2}= \\
49.01 / 147= \\
0.333\end{array}$ & & $\begin{array}{c}\mathrm{F}_{\alpha(\mathrm{K}-1)}, \\
(\mathrm{N}-\mathrm{K}) \\
12.354\end{array}$ & \\
\hline Total & $\begin{array}{c}\mathrm{SS}_{\mathrm{T}}= \\
\mathrm{SS}_{\mathrm{B}}+\mathrm{SS}_{\mathrm{W}}= \\
60.001\end{array}$ & $\begin{array}{c}N-1= \\
150-1= \\
149\end{array}$ & & & & \\
\hline
\end{tabular}

From the above table, it is clear that the value of F Calculated is 16.466, which is greater than the value of $\mathrm{F}$ Tabulated, which is 12.354 . As a result, the null hypothesis is rejected at $\alpha=0.05$. Consequently:

"There is difference of statistical significance among the respondents' opinions about implementing concepts of data mining technology in managing operations at Lebanese banks, which refer to difference in experience, job level or qualifications." 


\subsubsection{The Variable 'Qualifications'}

After analyzing the 44 questions of the second section (6 domains) as related to the first hypothesis, the difference between these results and the variable 'qualifications' in the demographic information as follows:

Table 16. Mean and standard deviation

\begin{tabular}{cccc}
\hline & \multicolumn{2}{c}{ Confidence Interval for Mean 95\% } & Std. Deviation \\
\hline Qualification & $\mathbf{N}$ & Mean & 0.497 \\
Lower than a B.A. & 16 & 2.031 & 0.643 \\
B.A & 56 & 1.763 & 0.600 \\
Masters & 69 & 2.080 & 0.641 \\
Ph.D & 9 & 1.409 & 0.634 \\
Total & 150 & 1.916 & \\
\hline
\end{tabular}

Table 17. Results of one way anova test

\begin{tabular}{|c|c|c|c|c|c|c|}
\hline Source of Variance & Sum of squares (SS) & df & Mean squares & $\begin{array}{c}\mathrm{F} \\
\text { Calculated }\end{array}$ & $\begin{array}{c}\mathrm{F} \\
\text { Tabulated }\end{array}$ & Sig. \\
\hline Between Groups & $\begin{array}{l}\mathrm{SS}_{\mathrm{B}}= \\
5.687\end{array}$ & $\begin{array}{c}K-1= \\
4-1= \\
3\end{array}$ & $\begin{array}{c}\mathrm{S}_{\mathrm{B}}^{2}= \\
5.68 / 3= \\
1.896\end{array}$ & $\begin{array}{c}\mathrm{S}_{\mathrm{B}}^{2} / \mathrm{S}_{\mathrm{W}}^{2} \\
1.89 / 0.372 \\
=5.095\end{array}$ & & 0.000 \\
\hline Within Groups & $\begin{array}{l}\mathrm{SS}_{\mathrm{W}}= \\
54.314\end{array}$ & $\begin{array}{c}N-K= \\
150-4= \\
146\end{array}$ & $\begin{array}{c}\mathrm{S}_{\mathrm{W}}^{2}= \\
54.3 / 146= \\
0.372\end{array}$ & & $\begin{array}{c}\mathrm{F}_{\alpha(\mathrm{K}-1)}, \\
(\mathrm{N}-\mathrm{K}) \\
3.857\end{array}$ & \\
\hline Total & $\begin{array}{c}\mathrm{SS}_{\mathrm{T}}= \\
\mathrm{SS}_{\mathrm{B}}+\mathrm{SS}_{\mathrm{W}}= \\
60.001\end{array}$ & $\begin{array}{c}N-1= \\
150-1= \\
149\end{array}$ & & & & \\
\hline
\end{tabular}

From the above table, it is clear that the value of $\mathrm{F}$ Calculated is 5.095, which is greater than the value of $\mathrm{F}$ Tabulated, which is 3.857. As a result, the null hypothesis is rejected at $\alpha=0.05$. Consequently:

"There is difference of statistical significance among the respondents' opinions about implementing concepts of data mining technology in managing operations at Lebanese banks, which refer to difference in experience, job level or qualifications."

\section{Conclusions and Recommendations}

Based on all the above, the following results were obtained:

There is interest in applying concepts of data mining in managing operations in Lebanese banks.

There is difference of statistical significance among the respondents' opinions regarding applying concepts of data mining in managing operations in Lebanese banks.

There is difference of statistical significance among the respondents' opinions regarding applying concepts of data mining in managing operations in Lebanese banks related to difference in experience.

There is difference of statistical significance among the respondents' opinions regarding applying concepts of data mining in managing operations in Lebanese banks related to difference in job levels.

There is difference of statistical significance among the respondents' opinions regarding applying concepts of data mining in managing operations in Lebanese banks related to difference in qualifications.

Based on the results of the study, the researchers recommends the following:

Enhancing the relation among all IT systems presently applied at the Lebanese banks and benefiting from the IT outputs to be inputs in other banking systems; in addition to training the appropriate human cadres in order to boost their performance.

Selecting innovative IT systems and tools which can enhance the banking operations which may increase profits to shareholders.

Adopting the most updated concepts and tools in order to increase the efficiency of decision-making system to provide the suitable type of information at the right time to help redirect the deviation if it exists. 


\section{References}

Asan, Z. (2007). Examining the socioeconomic characteristics of customers using credit cards, with clustering analysis. The Journal of Social Sciences, 17, 256-267. Retrieved from: http://birimler.dpu.edu.tr/app/views/panel/ckfinder/userfiles/17/files/DERG_/17/256-267.pdf

Atiya, A. (2000). Accounting Information Systems (pp. 265-288). University of Alexandria Publishing House.

Burhan, M., \& Raho, G. (2001). Accounting Information Systems (2nd ed., p. 8). Amman: Manahej Publishing House.

Chitra K., \& Subashini, B. (2013). Data mining techniques and its applications in banking sector. International Journal of Emerging Technology and Advanced Engineering, 3(8). Retrieved from https://pdfs.semanticscholar.org/87da/9ade5ca2f0547c86e0d29f65ede5f544de90.pdf

Dahrawi, K. (2007). Accounting Information Systems in the Light of Information Technology (pp. 70-99). Modern University Office, Alexandria.

Devale, A. B., \& Kulkarni, R. V. (2012). Application of data mining techniques in life insurance. International Journal of Data Mining \& Knowledge Management Process, 2(4). https://doi.org/10.5121/ijdkp.2012.2404

Enderson, S. W., \& Lanen, W. N. (2002). Using Electronic Data Interchange (EDI) to Improve Efficiency of $\begin{array}{lllll}\text { Accounting Transaction. The Accounting Review, 77(4), } & \text { 703-729. }\end{array}$ https://doi.org/10.2308/accr.2002.77.4.703

Ener, R. M. (1992). Auditing in an EDP environment. The Internal Auditor, 49.

Ferguson, C., \& Novell, P. (1996). The Relationship between Machine Enjoyment, Computer Attitude and $\begin{array}{llll}\text { Computer Usage. Accounting and } & \text { Finance, }\end{array}$ https://doi.org/10.1111/j.1467-629X.1996.tb00302.x

Hamid, A. J., \& Ahmed, T. M. (2016). Developing prediction model of loan risk in banks using data mining. Machine Learning and Applications: An international Journal (MLAIJ), 3(1). https://doi.org/10.5121/mlaij.2016.3101

Han, J., Kamber, M., \& Pei, J. (2011). Data mining: concepts and techniques (3rd ed.). Margan Kaufman Publishing, USA. Retrieved from http://myweb.sabanciuniv.edu/rdehkharghani/files/2016/02/The-Morgan-Kaufmann-Series-in-Data-Manage ment-Systems-Jiawei-Han-Micheline-Kamber-Jian-Pei-Data-Mining.-Concepts-and-Techniques-3rd-Editio n-Morgan-Kaufmann-2011.pdf

Helms, G., \& Mancino, T. (1998). Electronic Auditor. Journal of Accountancy, On-line Issues. Retrieved from https://www.journalofaccountancy.com/issues/1998/apr/helms.html

Hussein, A. (2004). Accounting Information Systems: Theoretical Framework And Application Systems (p. 24). Alexandria.

International Federation of Accounting. (1995). Codification of International Standards on Auditing. Auditing in a Computer Information Systems Environment, (401), 131-135.

Islam, R., \& Habib, A. (2015). A data mining approach to predict prospective business sectors for lending in retail banking using decision tree. International Journal of Data Mining \& Knowledge Management Process, 5(2), 13-22. https://doi.org/10.5121/ijdkp.2015.5202

Jayarsee, V., \& Balan, R. V. S. (2013). A review on data mining in banking sector. American Journal of Applied Sciences, 10(10), 1160-1165. https://doi.org/10.3844/ajassp.2013.1160.1165

Kalyani, M. R. (2012). Data mining techniques. International Journal of Advanced Research in Computer Science and Software Engineering, 2(10), 439-442. Retrieved from http://citeseerx.ist.psu.edu/viewdoc/download?doi=10.1.1.898.6657\&rep=rep1\&type=pdf

Kashef, M. Y. (2000). A Suggestion to Develop the Role of Accounting Information in the Light of the Integrated Concept of Quality Management. General Management Journal, 40(2), 445-484.

Kassem, A. (2004). Analyzing and Designing Accounting Information Systems (1st ed., pp. 20-26). Amman, Thakafa Publishing House.

Kelsy, M. (1994). The Human Resource Information System. Management Accounting, 75, 56-57.

Linoff, G. S., \& Berry, J. A. (2011). Data mining techniques: For marketing, sales and customer relationship 
management (3rd ed.). USA: Wiley Publishing.

Marakas, G. M. (2003). Decision Support Systems in the 21 st Century (pp. 432-439). Prentice Hall, NewJersy.

Michael, J., Berry, A., \& Gordan, S. L. (2000). Mastering Data Mining. John Wiley \& Sons, Inc.

Özekes, S., \& Çamurcu, A. Y. (2002). A classification and prediction application in data mining. Marmara University Journal of Science, 18, 1-17.

Page, J., \& Hooper, P. (1997). Accounting and Information Systems (p. 2). London: Prentice-Hall International, Inc.

Petre, R. (2013). Data mining solutions for the business environment. Database Systems Journal, IV(4).

Pliniussen, J. K. (1985). Information Networks for Computer Modelling. Cost \& Management Journal, 59(3), 53-57. Retrieved from http://www.dbjournal.ro/archive/14/14_3.pdf

Preethi, M., \& Vijayalakshmi, M. (2017). Data mining in banking sector. International Journal of Advanced Networking \& Applications (IJANA), 8(5), 1-4. Retrieved from https://www.ijana.in/Special\%20Issue/TPID01.pdf

Pulakkazy, S., \& Balan, R. V. S. (2013). Data mining in banking and its applications-A review. Journal of Computer Science, 9(10), 1252-1259. https://doi.org/10.3844/jcssp.2013.1252.1259

Raju, P. S., Bai, V. R., \& Chaitanya, G. K. (2014). Data mining: Techniques for enhancing customer relationship management in banking and retail industries. International Journal of Innovative Research in Computer and Communication Engineering, 2(1), 2650-2657. Retrieve from http://www.ijircce.com/upload/2014/january/21_Data\%20mining.pdf

Ramageri, B. M., \& Desai, B. L. (2013). Role of data mining in retail sector. International Journal on Computer Science and Engineering (IJCSE), 5(1), 47-50. Retrieve from http://www.enggjournals.com/ijcse/doc/IJCSE13-05-01-051.pdf

Romney, M. B., \& Steinbart, P. (2003). Accounting Information Systems (9th ed.). Upper Saddle River: Prentice-Hall.

Soumya, S. B., \& Deepika, N. (2016). Data mining with predictive analytics for financial applications. International Journal of Scientific Engineering and Applied Sciences (IJSEAS), 2(1). Retrieved from http://ijseas.com/volume2/v2i2/ijseas20160236.pdf

Sudhakar, M., \& Reddy, C. V. K. (2016). Two step credit risk assessment model for retail bank loan applications using decision tree data mining technique. International Journal of Advanced Research in Computer Engineering \& Technology (IJARCET), 5(3). Retrieved from https://ijarcet.org/wp-content/uploads/IJARCET-VOL-5-ISSUE-3-705-718.pdf

Tae, K. S., Namsik, C., \& Gunhee, L. (1999). Dynamics of Modeling in Data Mining: Interpretive Approach to Bankruptcy Prediction. Journal of Management Information Systems, 16(1), 63-85. https://doi.org/10.1080/07421222.1999.11518234

\section{Copyrights}

Copyright for this article is retained by the author(s), with first publication rights granted to the journal.

This is an open-access article distributed under the terms and conditions of the Creative Commons Attribution license (http://creativecommons.org/licenses/by/4.0/). 